\title{
PSHT Logo as Manifestation of Pancasila Ideological Values
}

\author{
Suryo Ediyono ${ }^{1 凶}$ \\ ${ }^{1}$ Universitas Sebelas Maret, Indonesia
}

DOI: http://dx.doi.org/10.15294/komunitas.v8i2.7322

Received : 2016; Accepted: 2016; Published: 30 September 2016

\begin{abstract}
This study aims to analyze and describe meanings on the symbols in the logo of martial arts school of Setia Hati Terate (here on called PSHT) and its representation towards the ideological values of Pancasila. The study is based on the Ethnosemiotical approach, an analysis method on cultural texts that relates the reading of symbol or picture of the PSHT logo with its meaning representation. The results conclude that the logo of PSHT imply a concordance between the philosophy and ideology of organization and the values of Pancasila treasured through Peircean semiotic perspectives. Almost all the entities in the logo of PSHT can be interpreted according to semiotical representamen and can be connected tothe confirming of the ideological state of Pancasila. In the symbol of bud, half-bloom, and bloom lotus which refers to the philosophical meaning of 'having stability and confidence in social skills, not feeling awkward and inferior in association' it is difficult to find the connotative and denotative meaning thus requires further clarification from the public who are involved in the organizations of PSHT. Identification of such symbols indicating the active- instillation on the values of Pancasila, among which are: uniting, maintaining and strengthening the unity of the nation, encouraging spirit of the nation in undertaking the national development and solving the arising problems in the life of the nation.
\end{abstract}

Keywords: martial arts; Pancasila; philosophical meaning; semiotics; values

\section{INTRODUCTION}

Having been positioned as a type of fighting technique which traditionally develops and becomes a pride for the people of Southeast Asia, Pencak Silat comes into existence as a local product of martial arts combining other combating arts of various forms and modifications (Alexander et al 1972, p.15). In Indonesia, there are officially about $\mathbf{8 2 0}$ schools of Pencak Silat (Wilson 2002; Ediyono 2005). In its early time, silat was initially a means of corroborating interactions between local communities' relationship with the kingdom and enhancing the capabilities of the state to prevent foreign interference and occupation. Later in the Dutch colonial era, martial arts cannot thrive because of the prohibition of practicing the local martial arts by the colonial government, while in the Japanese colonial period; martial arts were on its progressed. This occurs because the Japanese colonial colonialist gave people the freedom to train and practice the martial arts. Even by the Japanese government, there were often held games which gathered some masters of silat against the Japanese warriors (Ediyono 2012, p.20).

The symbol of Persaudaraan Setia Hati Terate (PSHT) 'has a deep meaning to the Javanese people supporting Pencak Silat martial arts. Persaudaraan (Brotherhood) in martial arts is understood as a bound of relationship which underlies unconditional priority of mutual trusting, needing, appreciating and forgiving in nature. Setia (faithful) implies meaning of unable to be separated, no matter how the circumstances was, the relationship is built upon love and deep

(c) 2016 Semarang State University. All rights reserved
p-ISSN $2086-5465$ | e-ISSN 2460-7320
(C) 2016 Semarang State University. All rights reserved
p-ISSN $2086-5465$ | e-ISSN 2460-7320

UNNDS JOURNALS

UNNES JOURNALS
Address: Faculty of Cultural Science, Universitas Sebelas

Maret, Housing Area of Banteng 3, Street of Tambora, Yogyakarta, Central Java, Indonesia

Email : ediyonosuryo@yahoo.com

Phone : +628157950734 
affection. Setia Hati (faithful heart) means a single entity united in the human's heart and mind that are oriented to God. Terate (lotus) is a type of beautiful and majestic flower and could survive anywhere. Philosophical meaning of Terate flower refers to the characters of the Setia Hati martial arts performers who should and are able to adapt or live a dignified life at all levels of society (Ediyono 2015, p.484).

Values in human conscience stands as a basic principle of morality which essentially becomes the standard of beauty and efficiency or integrity of conscience (potentiality). The initial steps of the value, just like the human's idea, is the basic potentiality of human beings. Value does not appear in the world of experience. But the real value is in the human soul. The values manifested in the ideology of Pancasila become a barometer of the Indonesian's lives, formed by Indonesia's first president of Sukarno as a pillar of the national independence. The core ideology of Pancasila values is summarized in the socio-religious nation of Indonesia that includes a belief in the Almighty God, attention to the aspects of humanism, national unity, democracy and social justice (Philips 2005, p.38). Basically Pancasila is an integrated ideal in which each part of them constitutes functions and duties. All the precepts in the Pancasila cover each function, meaning and duties as well as specific purposes. Philosophy of Pancasila as worldviews of the Indonesian is an objective reality that lives and thrives in society (Philips 2005, p.48). Pancasila instructs the nation to achieve prosperity to all of the Indonesian regardless of different ethnic backgrounds or race. All the law or rules in the life of the nation rely on the Pancasila. This fact makes the Pancasila always be enacted in the constitutional life.

Few studies have been done on the martial arts organizational members and schools in cultural semiotic analysis. Muzakky et al. (2015) examined the psychological dynamics comparison of group schools of Pencak Silat. Muzakky's study focuses on determining the level of aggression, pride and collective tolerance in three streams of Pencak Silat (Pagarnusa, Setia Hati Terate and Kera Sakti). The results showed that the Kera sakti martial arts group has a higher tolerance and aggression level, and lower personal pride. Suwaryo (2008) examined the role of martial arts organization in minimizing crime, a case study in Banjarnegara. This study focuses on the study of normative law with juridical method. The results showed that the role of martial arts organization in Banjarnegara district, Central Java as a non-penal means in minimizing crime cannot be done optimally, crime prevention efforts are still based on the law enforcement officers. Wilson (2002) examines the political power in the 'inner power' in the practice of martial arts in West Java. The results showed that the ongoing shift in socio-cultural condition influences society on the theory, practice and martial arts organizations in West Java. Meanwhile studies on cultural semiotic analysis have also been done by Baehaqie (2014) that studied the meanings of various colors of jenang mancawarna in offerings celebrationof Javanese people using ethnolinguistic approach, His study revealed that the four colors of jenang have semiotic meanings connected to the concept of papat lima pancer 'four directions; east, west, north and south'. Yanuartuti (2015) semiotically studied Wayang Topeng shows in Jombang. Her study concluded that Wayang Topeng indeed functions as a vow of ritual, a giver inner experience, a breadwinner, entertainment to form social solidarity.

Departing from previous studies, the need for studying symbols of the martial arts to determine the philosophical meanings of the schools or streams, their motivations and purposes introduced into the practitioners part of it becomes the ideology of the school towards the local community (Altintas and Tokol 2007; Christopher and Hickinbottom 2008; Saffu Walker and Mazurek 2010; Siemieniako 2011). Reviews of the philosophical meanings of the martial arts school's logo could imply result that the stream was consistent with the ideological values of the Indonesian State of Pancasila, 
it is quite important for the enhancement of the national characters in the present and future (Kuo and Chew 2009; MuratbekovaTouron 2008; Ryan et al. 2007; Tolia-Kelly 2006).

\section{RESEARCH METHODS}

This research applied ethnometodology paradigmn, especially the ethnography (Spradley 1997) and Peircean semiotic analyses (Noth 1995). The ethnosemiotic approach was applied to study the symbols and characterize the logo of PSHT martial arts group.Research data collection techniques applied was participant observation, in-depth interview with two key-informants (Nalapraya, chief of PSI, the Indonesian Silat Association and Tarmadji, chief of PSHT organization), documents and other literature studies. To be able to get subsequent information from informants, this study applied purposive sampling model of snowball sampling (Sutopo 2006). Qualitative data analysis employed in this study is under the ethnoscience methodology especially the taxonomic analysis, domain analysis and componential analysis to find themes of culture. The results are presented in a narrative text in the form of interactive analysis undergoing the cycle process (Sutopo 2006).

Semiotics consists of a set of theories to dissect reality of how the signs represent objects, ideas, circumstances, situations, feelings and conditions outside the sign itself. (Littlejohn 2009, p.53). Semiotic aims to determine the meanings contained in a sign or interpret such meanings so that becomes visible to the readers, or how the communicators construct the messages. In the application, semiotics does not only refer to the signs in everyday conversation, but also everything that refers to other forms such as words, images, sounds, gestures, and objects. Sobur (2004, p.13) explains the differences in language and signs; which accordingly, language is a sign system which is most fundamental to humans, whereas non-verbal signs such as gestures, forms of dress, as well as various social practices of other conventional can be viewed as a kind of language which is composed of mea- ningful signs communicated by relations. de Saussure called this semiotics concept as semiology which is a study on the roles of signs as part of the social life. For Peirce (1931) 'Semiotics was formal doctrine of signs which was closely related to logic'. Sign according to Peirce is 'something which stands to somebody for something in some respect or capacity'. He also said that every thought is a sign (Noth 1995).

According to Peirce, a sign becomes the explanatory representation on something the perceivable part of the sign a representament (literally' something that does the representing 'and 'the concept that it encodes the object (literally' something cast outside for observation'. He termed the meaning that someone gets from signing the interpretant. This formula implies that the meaning of a sign can be applied individually, socially or specifically depends on specific context. Representament serves as a marker. The object is something represented by representament which relates the reference. The object can be a mental representation (in mind), it can also be something outside the real sign. Interpretant is the meaning of the sign. Sign itself cannot reveal anything but to show the reality. The task of the interpreters is to give meaning based on experiences of the marker (Noth 1995, p.42-43; Zeugner-Roth Žabkar and Diamantopoulos 2015; Zolfagharian and Sun 2010).

Peirce's famous concept of triadic (the triangle analysis) in in his Semiotics consists of three elements, namely the sign, qualisign and sinsign. Qualisign, the word quali literally was taken from the word quality (quality, nature), which is a sign as signed by its nature. For example, the nature of striking red color is used in the making of stopping sign on the traffic light.

Sinsign, the word sin comes from the word singular (singular), which is a sign is based on events, shape, or distinctive and original form. For example, we may know someone from his or her distinctive voice. Monas a monument building in Jakarta may also contain sinsign because its shape and appearance is unique and distinctive from 
others.

Legisign, the word legi is derived from the word lex (the law), which is a sign that becomes sign because it has pattern as a principle or rule. This type of signs can be exemplified by the structure of grammar.

Pencak Silat studies have been researched by some researchers across countries. In essence, there is no a truly single sign for all is a combination of the encoded elements. Therefore, in terms of everything, this basically can refer to so a called symbolic signs.

\section{DISCUSSION}

The Ethnosemiotic approach includes a culturally search to the messages on the signs in the forms of images and texts which construct philosophical meanings of Setia Hati martial arts school's logo. The following descriptions provide a brief study about the school, flow, historical and the ideological values of PSHT organisation. The descriptions of PSHT organization along with the historical establishment is the cultural attributes operated to help the interpretations on the underlying philosophical meanings of the logo's organization. As an ethnosemiologist, the writer analyzes the systems of signifiers which are individuated in specific cultural contexts through the observation and the application of the ethnographic methods (Wikipedia 2016). Ethnosemiotics is a text analysis method which connects readability of the text, form of images to explore philosophical meaning from the public readers. The study on such images requires an intense understanding of PSHT organizational symbols of religion (Islam) and Javanism (Kejawen) so that it will gain the ethnosemiotical senses of prominent fighters.

\section{Pencak Silat, Pendekar and Aliran}

Pencak Silat is a compound term consisting of two words used to refer to a kind of traditional martial art. The phrase "pencak silat" is derived from the word 'penca' (West Java) and 'Mancak' (Madura and Bali) which is commonly used in Java, Madura and Bali, while the term 'silat' or 'Silek' were used by the people of Sumatra (Alexander et al 1972, p.15). Ambition to bring together all these different cultural expressions into the more general use of terminology was initiated in 1948 by forming the Indonesian Pencak Silat Association (Ikatan Pencak Silat Indonesia, IPSI). Then shortly after that, the representatives of each school of silat formally approved the use of the term 'pencak silat' as a legal term in Indonesia, although the original terms may still widely used at the local level (Maryono 2009, p.2; Saiful Aziz 2011; Wilson 2002, p.294).

People who have certain skills to defend themselves and have undergone the ritual activities to acquire a degree of particular religiosity were honored in their communities as leaders, often called 'master or a competent', in Malay word this is so called 'pandai'. The term 'pandai' in the actual use of Malay means an expert (of any field). In martial arts, the term pandai refers specifically to the people who are able to control some supernatural powers. Then the word pendekar 'warrior' used to refer to an expert of silat is likely derived from the root word pandai 'intelligent'. According to Malay people, the word pendekar is often associated with the term 'intelligent root'(skillful in using intelligence). Similarly, a pendekar has to do with a great rank and leader in community, the characteristics of pendekar as many acknowledged by the community are among those who posses physical immune or invulnerable.

Along with the development, martial arts practitioners known as warga 'citizens' have developed various styles of martial arts to what they called as aliran 'stream'. This term has similar meaning to style. The understanding of aliran in the perspective of martial arts is a set of techniques and methods of resistance that are passed from generation to generation and is managed by the leader of sect (Wilson 2002, p.292). In the world of martial arts, aliran is not ideology or school of thought, and only relates to having different physical practices. Pencak silat whatever stream it has remains inspired and motivated by the philosophy of noble mind and covers aspects of mental-spiritual 
as an instrument of self-control.

\section{Pencak Silat Setia Hati Terate (PSHT)}

PSHT (preceded by the establishment of Sedulur Tunggal Kecer) was founded by Ki Ngabei Soero Diwiryo of Madiun in 1903 in the village of Tambak Gringsing Surabaya. In the early time of the establishment, Ki Ngabei did not name his school Setia Hati, but Joyo Gendilo Cipto Mulyo School. This school initially consisted of 8 students, preceded by two brothers namely Noto or Gunadi (younger brother of KI Ngabei) and kenevel of Netherlands (Imron 2003, p.1). According to local information, Ki Ngabei Soero Diwiryo had 2 favorite students and shortly after the death of him, there was a conflict of Setia Hati ideology between the two students who were led to the outbreak of the school into two divisions, namely Setia Hati Winongo which remains centered in the village of Winongo and Setia Hati Terate in the Village of Pilangbangau, Madiun (personal communication Nalapraya, December 13, 2012; Imron 2003, p.8).

\section{The ideology of Pencak Silat Setia Hati Terate (PSHT)}

Based on the organizational source document of PSHT, there literally said that Ki Ngabei Soero Diwiryo was a descendant of Bethoro Katongdi Ponorogo, son of King Brawijaya in Majapahit. The Setia Hati itself is an acronym for Java poem that contains a philosophy of life and the Javanism ${ }^{1}$ (Kejawen). The acronym as follows;

\section{S Setyo Budyo, Sinupeket singset E \\ T Tiniti Aliring Tinati I}

A Hanggayuh Pandeme Ngawiryo H Hamarsudi Handaraning Wiwoho A

\section{T Tinulato Ing Reh Mengestuti \\ I}

In the Indonesian sense, the poem means 'the good behavior or personality is a major thing that should always be adhered to and accompanied the life steps to reach primacy in order to create a peaceful world. This philosophy would then become the core teachings of Setia Hati.

\section{Noble Values of Pancasila in Pencak Silat}

In general, individuals who belong to a martial arts school will be formed into the loyal communities to the state. As a means of exercise, martial takes a role as an instrument connecting practitioners with traditional practices in the community. In addition, the martial arts definition includes four aspects, namely sports, martial arts and spiritual soul. (Wilson 2002, p.259). Thus, any practitioner of martial arts is required to undergo a consistent practice. Both the ideological values of Pancasila and philosophy of noble character in the martial arts are a single entity whose essence is 'Prasetya Pesilat Indonesia'. 'Prasetya Pesilat Indonesia' is the essence of noble values of Indonesian pencak silat which is realized in the form of pledges. The prasetya 'vow' place the Indonesian people of martial arts both as a citizen and fighter of ideal knight whose duties are to carry a number of obligations (Ediyono 2012, p.71).

\section{Noble Values of Pancasila Summarized in the Logo of PSHT}

Before delving deeper into the philosophy of pencak silat school of Setia Hati, the researcher would like to impose limits on Peircean opinion. In this study, if we look at an object which is directed toward goal, our attention will be focused on the logo of PSHT. Logo as a visual communication media describes the identity of an institution. It contains the spirit at the same time describing the spirit of the vision and mission of the institution. Obviously a logo must appear strong in a variety of media. The Strength of logo can be built through consistency which is consciously constructed in a variety of events. Murphy and Rowe, (1998, p.7) argue that every product or a successful organization has its own personality and complex human personality, the personality of the martial arts organization share the same perspective. 


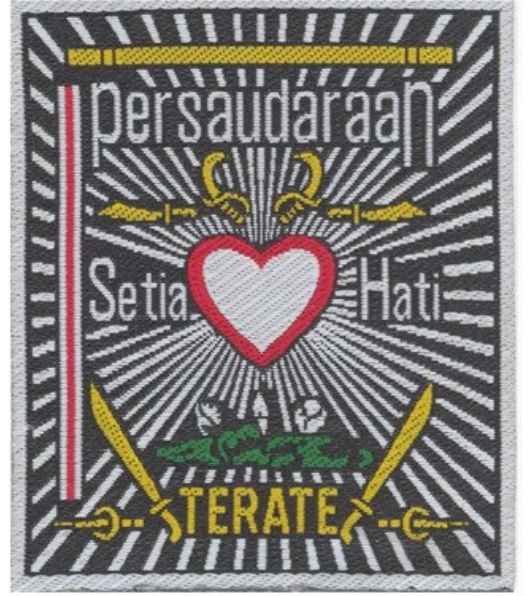

Figure 1. The Martial Arts School Logo of Persaudaraan Setia Hati Terate by Priyo, Yogyakarta (Source: Personal Documentation)

1. The Belief in the Almighty God. The first principle asserts that every citizen should recognize the existence of God,imilarly, the practitioners of martial arts Setia Hati. Deity teachings of officially recognized religions in Indonesia are discussed implicitly on the logo of PSHT through heart-rays. Heart-rays symbolizes the purity and greatness of a soul. When the heart becomes sacred, the soul remains tranquil. The concept of Almighty God manifested in PSHT logo can be understood from the philosophy emission of the heart purity which is a form of piety and devotion to the Almighty God, Allah. The steady conviction accompanied by good deeds to the self and others will emit light. The glow hearts can be seen through a face, a person who has received the guidance of Allah as though his/her face took emit light (personal communication, Tarmadji, December 6, 2012).

2. Being Just and Civilized Humanity. The second principle reflects their human rights as symbolized by the red and white perpendicular lines. This symbol describes that a citizen or PSHT practitioners must stand firmly on the truth and justice. Justice is based on a principle that dauntless because of right and fear because of wrong. Practitioners of Setia Hati martial arts group are always fair and impartial to the right even if the truth is in the other people.

3. The unity of Indonesia. The value of Indonesian nationalism in the logo of PSHT on this principle is reflected in the philosophical meaning of the word 'fraternity or brotherhood' symbolizes the unity and integrity as a united nation. The word 'brotherhood' indicates that this organization is based on brotherhood and compassion towards their fellow creatures, especially humans. This brotherhood will be realized when people are loyal to each individual conscience and not discriminating people on their levels of intelligence and classes. The represented meanings of PSHT symbols is centered on the essence of brotherhood.

4. Citizenships who live according to the wisdom of deliberation and representation (spirit of democracy). This principle confirms that the Indonesian nation will continue to maintain and develop the spirit of deliberation to reach a consensus based representation. The logo of PSHT which represents this principle is on the image of heart picture bounded with the white and red rectangular line.

a) The symbol of heart with whitered bordered line indicates the philosophical meaning of pure love is restricted by the earnest inner consideration. This symbol encapsulates the concept of deliberate democracy and anger management in socializing with others. The red line means a limiting love because a love has no limits it will turn to be disastrous. The courage of a warrior is always based on the sanctity and truth of his/her religion. Being brave or courage does not mean expecting the arrival of danger and disaster. The danger is not to be sought, but should be avoided instead. A courageous without understanding will result brutality. Conceptually, a really brave 
people are those who love the life and consider it a blessing, if it once lost, it will not be recovered (personal communication, Nalapraya, December 13, 2012).

b) The symbol of four rectangles represents the Mecca describing the authoritative managements on the five directions, of east, north, south, west, and five human personalities, the essence of authoritative management of human lusts and desires. In running their lives, men will face four lusts. Amarah 'anger' is the leader of the other lusts. If one's desires are not fulfilled then the amarah lust is likely to encourage people to do things in destructive forms, such as fighting, burning, destroying, and killing. Lawwamah is a lust oriented towards corporeal or biological, such as eating, drinking, and sexual relations. The resulting characteristics are greedy, envious, spiteful, and wasteful. Sufiah is a lust oriented towards the needs of spirituality (immaterial), such as love, pride, beauty, and romance. The resulting characteristics are overbearing, arrogant, lying, and envy. Mutmainah is a lust encouraging a person to be devotional and piety to God, enjoying good, virtue, and noble character. The resulting characteristics are honest, fair, and forgiving (personal communication, Tarmadji, 2012).

The fourth principle of Pancasila reflects the government's focus on a guiding democracy. PSHT is one of the martial arts school incorporated in the Indonesian Pencak Silat Association (IPSI). Significantly, the presence of PSHT formal role is also a form of government interference primarily in guiding to the local martial arts school organizations. Thus, PSHT was given its right and obligations in the Indonesia Republic constitution as cited on the Chapter
11, No. 3, 2005 regarding the system of national sports as follows:

(1) The Government and local authorities have the right and steer, guide, assist and supervise the sports in accordance with the constitutional laws and regulations.

(2) The government and local government are obliged to provide careand services aswell as ensuring the sports activities for every citizen without discrimination.

5. Social Justice to all of Indonesian people. This preception affirms the principle of justice and prosperity. Justice is in terms of life, both materially and spiritually. A reflection of the values of justice and prosperity can be seen from the use of the white lines perpendicular and buds, half bloom and blossom lotus symbols.

a) The perpendicular white lines symbolize that practitioners or citizens of PSHT must stand firmly on the truth and justice, act dispassionately and stand on the right side even if it the true was someone else.

b) Buds, half-bloom and bloom lotus. These images symbolize the stability and confidence consequently the practitioners would never feel awkward and discriminated in socializing to anyone. The true pendekar/pesilat 'warrior' will never feel higher even lower than anyone confronting him. This character describe the prohibition of practitioners to live their live neither to be arrogant nor to let himself feeling humiliated. If by chance these practitioners were bestowed by God with blessing, it will be generously given to the need and when they are in weakness or deficiencies they will never hide and let them being corrected by others. Deficiencies or weaknesses in essence is a disease that would easily be treated and 
cured if the disease has successfully been diagnosed. Moreover, it also symbolizes levels of human life. There are those who live under poor, middle or moderate conditions and there are those who live life fanciness. These three levels of economic situations are different in nature. However, whatever situations someone may live with, all of them should share honors in the existing layers of society, a reminder to oneself that everyone is the same before the Almighty God and also as equal creatures in PSHT.

If we wish to make each principle into a typological, then representament points which encapsulates the values of in the PSHT philosophy will be consistent with the ideological values of Pancasila:

1. The Ethical Value (aspects of mental and spiritual) covers the devotional attitude and characteristic to the Almighty God and noble character, patriotism, strong sense of fraternity and responsibility, such as forgiveness and solidarity through upholding the truth, honesty, and fairness.

2. The Technical Value (the martial aspects) covers the nature and attitudes of both mental and physical alertness of fortified and responsive chivalry and always apply their martial arts skills in the right way, avoiding oneself from being arrogant and having animosity.

3. The Aesthetic Value (artistic aspects) covers the attitude and nature of loving the national culture. This value lays on a principle of martial arts oriented toward a cultural nation of worth and sublime perceived, to strengthen the national identity, strengthen self-esteem and national pride as well as the spirit of unity.

4. The Athletic Value (sports aspects) covers the attitude and character which ensures the physical and spiritual health, and achievement in the area of sports. This means that the awareness and obligation to practice and implement the martial arts out of life as a sport lays on a principle that regards it as a part of everyday life activities, such as to gain more achievement. Facing a match must uphold sportsmanship. In this sense, both the noble values of Pancasila and martial arts are the unifying principles which eventually must be consistently implemented by all the Indonesian martial arts communities.

Based on the interpretation on the findings, there is a relevant relationship between values reflected in the symbols of PSHT and ideology of ones in Indonesian Pancasila. The conformity between signs that represent the values of the state ideological analysis confirmed the Piercean Semiotic theory. According to Peirce, one of the forms of sign is a word, like the word Persaudaraan 'fraternity or brotherhood' in the logo of PSHT. While the object is something which is referred to the sign, for example the picture of 'perpendicular white lines ', conceptually represents the philosophical meaning of 'the citizens of PSHT' that is to stand firmly on the truth and justice'. While interpretant is a sign which exists in someone's mind about the object of reference functioning as a sign For example, fair attitude is usually associated with the figure of a judge and so forth. Almost all of the PSHT logos can be interpreted according to their semiotic representamen and thus relevantly affirm the ideological values of Pancasila. However, the symbol of bud, half bloom and bloom lotus refers to the meaning of steadiness and confidence which would seem difficult to find the relations of both connotative and denotative meanings, therefore, the semiotic meaning in this case requires further clarification from the members of PSHT organization.

These three elements of Peircean model of analysis interact in the minds of both PSHT supporters and the public in general who understand the science of sign, thus the philosophical meaning of such signs can be clear presented (Sobur 2004, p.115). According to the data, all signs imply that the 
ideological role of institutions become an important instrument for the organization's messages conveyed through images or symbols in the PSHT logo. In general, the philosophical meanings of PSHT logo can be simplified into some ideologies such as maintaining and confirming the national unity, encouraging nations to build a strong sense and spirit of the nationality and solving problems among the people united in a country and nationality.

\section{CONCLUSION}

In general, this study is intended to provide philosophical understanding toward the meanings on the logo of Pencak Silat Setia Hati Terate (PSHT). All the presented results were an attempt to elaborate the Peircean perspective on Semiotic analysis applied into an organizational logo. It can mainly be concluded that any sign cannot be interpreted and treated as an entity which contains static meaning, but rather it should be defined in various ways according to some limits given by the users. The limitations of the signs reflected on the logo of PSHT are fully depending on the aims and ideological messages underlying such martial arts organization. The results conclude that the logo of PSHT imply a concordance between the philosophy and ideology of organization and the values of Pancasila treasured through Peircean semiotic perspectives The result showed that on the symbol of bud, half-bloom and bloom lotus whic refers to the philosophical meaning of 'having stability and confidence in social skills, and not feeling awkward and inferior', it is difficult to find the connotative and denotative meaning and thus requires further clarification from the public who is involved in PSHT organization. Identification of such symbols indicates the active-enterprising of the instillation on the values of Pancasila, that is, uniting , maintaining and strengthening the unity of the nation and the moving spirit of the nation in undertaking the national development, and solving the arising problems in the life of the nation.

\section{REFERENCES}

Alexander, H.. Chambers, Q., Draeger, D.F., 1972. Pentjak-Silat, the Indonesian Fighting Art. Kodansha International, Ltd., Tokyo \& California.

Altintas, M.H. and Tokol, T., 2007. Cultural openness and consumer ethnocentrism: An empirical analysis of Turkish consumers. Marketing Intelligence E Planning, 25(4), p.308.

Baehaqie, I., 2014. Jenang Mancawarna Sebagai Simbol Multikulturalisme Masyarakat Jawa. Komunitas: International Journal of Indonesian Society and Culture. 6(1), pp.180-188.

Christopher, J.C. and Hickinbottom, S., 2008. Positive psychology, ethnocentrism, and the disguised ideology of individualism. Theory $\mathcal{E}$ psychology, 18(5), pp.563-589.

Ediyono, S., 2012. Pencak Silat - Filosofi dan Makna Budi Pekerti. Tesis: Pascasarjana Universitas Gadjah Mada

Ediyono. 2015. Laku Ritual dalam Tradisi Pencak Silat. Indigenous Knowledge and Cultural Heritage for the Sustainable Development. International Conference Nusantara Philosophy (ICNP) 2015.

Facal, G., 2014. Silat Martial Ritual Initiation in Brunei Darussalam. Southeast Asia: A Multidisciplinary Journal, 14.

Imron, R., 2003. Social Conflict: Notes from (East Java). Journal Conflict Negoitation Study.

Kuo, E.C. and Chew, H.E., 2009. Beyond ethnocentrism in communication theory: Towards a culture-centric approach. Asian journal of communication, 19(4), pp.422-437.

Littlejohn, S.W., 2009 . Teori Komunikasi Theories of Human Communication edisi 9. Salemba Humanika, Jakarta.

Maryono, O., 1999. Pencak Silat in the Indonesian Archipelago, RAPID Journal, 4(2).

Moleong, L.J., 2004. Metode Penelitian Kualitatif. PT Remaja Rosdakarya, Bandung.

Muratbekova-Touron, M., 2008. From an ethnocentric to a geocentric approach to IHRM: The case of a French multinational company. Cross Cultural Management: An International Journal, 15(4), pp.335-352.

Murphy, John \& Rowe, M., 1998. How to Design Trademarks and Logos. North Light Book, Ohio.

Muzakky, I., Novitasarim, U.D., \& Hamidah, S., 2015. 'Comparative Study Dynamics of Psychology of Pencak Silat Groups (Iks. Pi Kerasakti, Persaudaraan Setia Hati Terate, and Pagarnusa), Global Journal of Business and Social Science Review, (1), 1.

Nazir, M., 2003. Metode Penelitian. PT Ghalia Indonesia, Jakarta.

Nöth, W., 1995. Handbook of Semiotics. Indiana University Press, Bloomington and Indianapolis.

Opcit Kumpulan Materi Ke-Sh-An Persaudaraan Setia Hati Terate. Retrieved (https://www. 
academia.edu).

Phillips, D.A., 2005. Mondern World Nations Indonesia. Chelsea House Publishers, Philadelphia.

Ryan, C.S., Hunt, J.S., Weible, J.A., Peterson, C.R. and Casas, J.F., 2007. Multicultural and colorblind ideology, stereotypes, and ethnocentrism among Black and White Americans. Group Processes $\mathcal{E}$ Intergroup Relations, 10(4), pp.617-637.

Saffu, K., Walker, J.H. and Mazurek, M., 2010. The role of consumer ethnocentrism in a buy national campaign in a transitioning country: Some evidence from Slovakia. International Journal of Emerging Markets, 5(2), pp.203-226.

Saifulaziz, A., 2011. Nilai-nilai Luhur dalam Pencak Silat. Retrieved (http://ahdasaifulaziz. blogspot.co.id).

Siemieniako, D., Kubacki, K., Glińska, E. and Krot, K., 2011. National and regional ethnocentrism: a case study of beer consumers in Poland. British Food Journal, 113 (3), pp.404-418.

Sobur, A., 2004. Semiotika Komunikasi. Cetakan Kedua. Remaja Rosdakarya, Bandung.

Spradley, J.P., 1997. Metode Etnografi [Trans. Misbah Zulfa Alizabeth]. Tiara Wacana, Yogyakarta.

Sutopo, H.B., 2006. Metode Penelitian Kualitatif. Universitas Sebelas Maret Press, Surakarta.

Suwaryo. 2008. Peranan Organisasi Perguruan Seni Beladiri Pencak Siat dalam Meminimalisasi Kejahatan. Tesis. Program Magister Ilmu Hukum, Pascasarjana Universitas Diponegoro.

Tolia-Kelly, D.P., 2006. Affect-an ethnocentric encounter? Exploring the 'universalist'imperative of emotional/affectual geographies. Area, 38(2), pp.213-217.

Undang-Undang Republik Indonesia Nomor 3 tahun 2005 tentang Sistem Keolahragaan Nasional,
Op.cit., hal.9.

Wikipedia. 2016. Ethnosemiotics. Retrieved (https:// en.wikipedia.org/wiki/Ethnosemiotics)

Wilson, I.D., 2002. The Politics of Inner Power: The Practice of Pencak Silat in West Java. [Ph. D Disertation]. School of Asian Studies, Murdoch University, Western Ausralia

Yanuartuti, S., 2015. The Life of Mask Puppet in Jombang: Its Functions and Contnuity. Komunitas: International Journal of Indonesian Society and Culture. 6(2), pp.222-236.

Zeugner-Roth, K.P., Žabkar, V. and Diamantopoulos, A., 2015. Consumer ethnocentrism, national identity, and consumer cosmopolitanism as drivers of consumer behavior: A social identity theory perspective. Journal of international marketing, 23(2), pp.25-54.

Zolfagharian, M.A. and Sun, Q., 2010. Country of origin, ethnocentrism and bicultural consumers: the case of Mexican Americans. Journal of Consumer Marketing, 27(4), pp.345357.

List of key-informants:

1. Eddy M. Nalapraya (66 years old, Chief of IPSI martial arts school), Jakarta.

2. H.Tarmadji, SE. (52 years old, General Chief of PSHT), Madiun.

Note:

(Endnotes)

1 Kejawen is not in the category of religion, but refers to an ethics and a style of life inspired by Javanist thinking. In this sense, one can be regarded as following this life paradigm if only they take reference of life beings from historical figures in wayang or kejawen. 